\title{
Relationships among Pulmonary Function Tests, Diffusing Capacity, Gas Exchange and Haemodynamics in Pulmonary Hypertension
}

\author{
Airò E*, Bauleo C, Ripoli A, Formichi B, Pavlickova I, Grotti F, Catapano G, Monti S, Mannucci F, Ndreu R and \\ Prediletto R \\ Institute of Clinical Physiology, National Research Council-Tuscany Region “Gabriele Monasterio Foundation”, Italy
}

Submission: April 22, 2017; Published: May 31, 2017

*Corresponding author: Airò E, Institute of Clinical Physiology, National Research Council-Tuscany Region “Gabriele Monasterio Foundation”, Italy, Tel: 0039-0503152216; Fax: 00390503152166; Email: predile@ifc.cnr.it

\section{Introduction}

The functional work-up in the diagnostic process of pulmonary hypertension is usually based on the measure of pulmonary function tests and arterial blood gases to identify underlying airway or parenchimal disease [1].

\section{Aim}

We wondered if there could be a mutual interchange of information among variables, i.e., indices of pulmonary function tests (spirometry, diffusion), blood gases $\left(\mathrm{paO}_{2}, \mathrm{paCO}_{2}\right)$, gas exchange (A-a $\left.\mathrm{DO}_{2}, \mathrm{a}-\mathrm{ADCO}_{2}, \mathrm{VDphy} / \mathrm{VT}\right)$ and haemodynamic variables (such as RAP, mPAP, CI, PVR) in a population of $\mathrm{PH}$ patients. This was done in order to understand much better the potential role of each variable in the work-up of this disease

\section{Methods}

Sixteen patients with clinical suspicion of pulmonary hypertension under went a complete spirometry. Diffusing lung capacity, blood gases analysis, gas exchange, physiological dead space to tidal volume were measured as well as haemodynamic indices.

\section{Statistical methods}

Mean values and their standard deviation were calculated. The relationships between the observed variables were evaluated by their mutual information. Because of the very low error rates shown with small sample sizes, the global network was reconstructed using the ARACNE algorithm [2]. Modules in the network were identified applying a multi dimensional scaling procedure to the adjaceny matrix and, succesively, clustering the variables with a model-based bayesian approach [3]. We conducted the analyses with R statistical software.

\section{Results}

Out of 16 patients, 14 were women (87.5\%), mean age ( $50 \pm 15$ years); 10 resulted affected by idiopathic pulmonary arterial hypertension; 4 by connective tissue disease associated pulmonary hypertension; 2 by chronic thromboembolic pulmonary hypertension. All patients were naive (no specific therapy). One patient demonstrated a mild reversible obstruction where as two a mild restriction. Diffusing lung capacity was $69 \%$ of predicted. Patients were affected by a moderate to severe form of pulmonary hypertension (mPAP $44 \pm 13 \mathrm{mmHg}$ ), all were affected by pre capillary pulmonary hypertension (PCW $6 \pm 3 \mathrm{mmHg}$ ); pulmonary vascular resistances were increased in all patients (PVR $7 \pm 3 W U$ ). Two patients had hypoxemia ( $\mathrm{PaO} 2$ less than $60 \mathrm{mmHg}$ on room air). Pulmonary gas exchange was on average impaired with increased A-a DO2 (35 \pm 18$)$, as well as physiological dead space thus indicating impairment of ventilation perfusion distribution ratio.

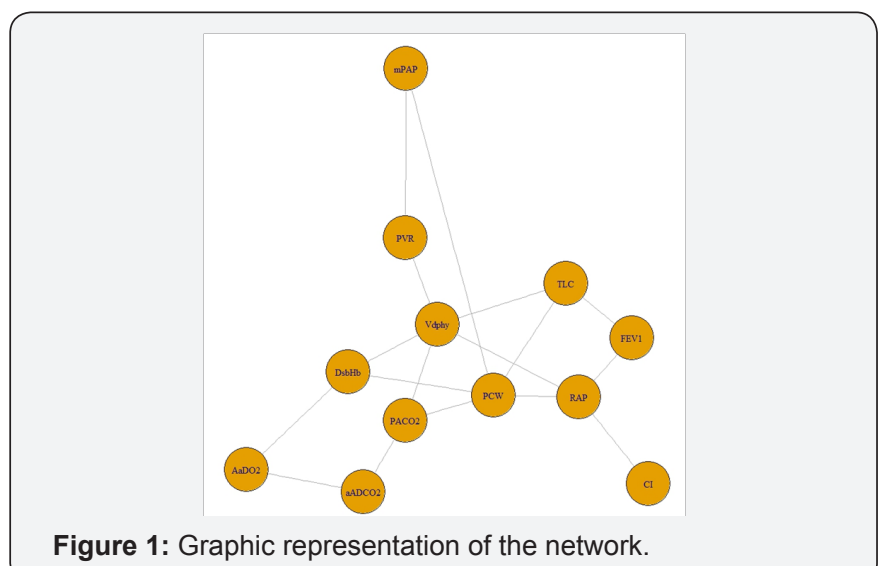




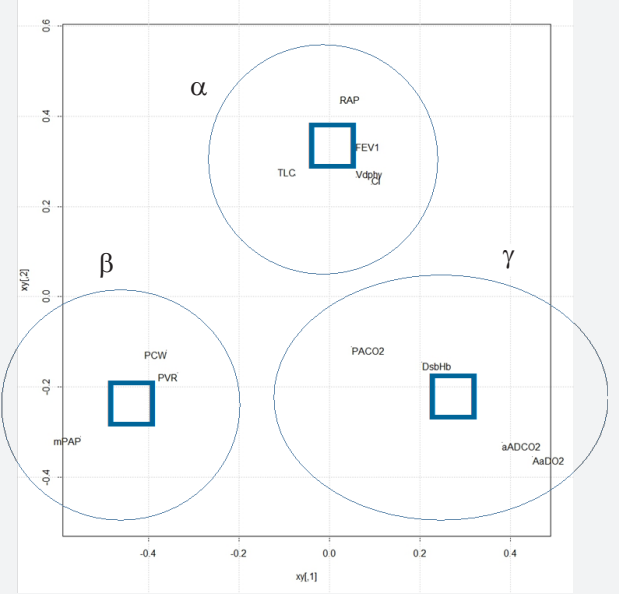

Figure 2: Three modules were identified in the network.

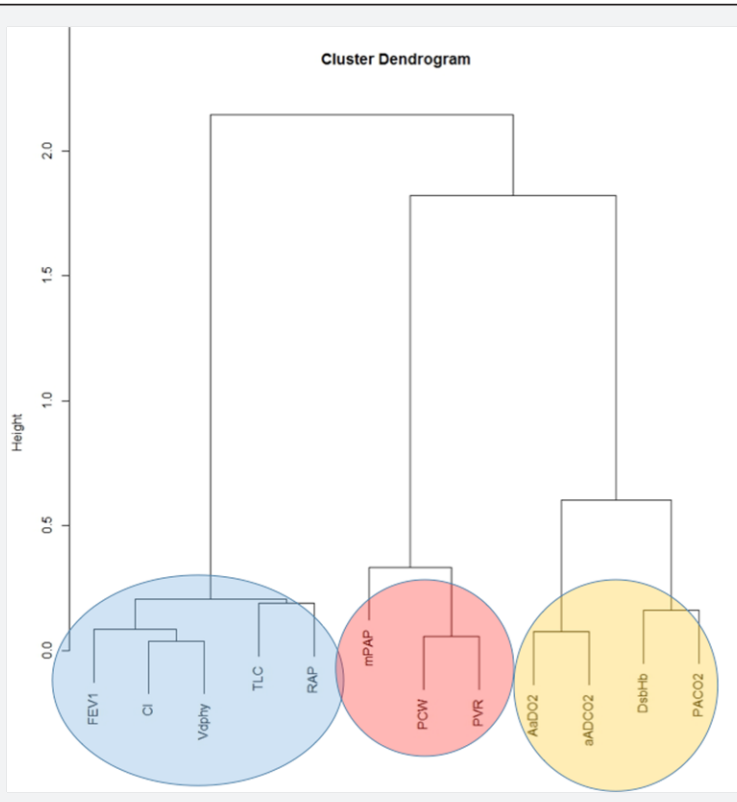

Figure 3: The three modules were well separated.

The three most influential variables in the network (Figure 1) were: PCW (betweeness=20), RAP (betweeness=18) and VDphy/ VT (betweeness=14). Three modules were identified (Figure 2): module alpha (RAP, FEV1, VDphy/VT, CI, TLC); module beta (PCW, PVR, mPAP); module gamma (aADO2, aADCO ${ }_{2}, \mathrm{DsbHb}$, $\mathrm{PaCO}_{2}$ ). The three modules were well separated (Figure 3).

\section{Discussion and Conclusion}

Since Pulmonary Arterial Hypertension is characterized in part by increased dead space ventilation, being a disease of vascular obstruction, many observations deal with the role of non invasive tool of gas exchange as prognostic marker [4]. The results of our study seem to go along with this prospective. In fact, it turns out from our results, especially from module alpha, the narrow relationships between gas exchange parameters
(VDphy/VT) and RAP or CI, well known predictors of mortality. Thus, gas exchange should be incorporated in the evaluation of patients evaluated and monitored for $\mathrm{PH}$.

\section{References}

1. Jing ZC, Xu XQ, Badesch DB, Xin Jiang, Yan Wu, et al. (2009) Pulmonary function testing in patients with pulmonary arterial hypertension. Respir Med 103(8): 1136-1142.

2. Margolin AA, Nemenman I, Basso K, Wiggins C, Stolovitzky G, et al. (2006) ARACNE: an algorithm for the reconstruction of gene regulatory networks in amammalian cellular context. BMC Bioinformatics 7(Suppl 1): S7.

3. Fraley C, Raftery AE (2002) Model-basedclustering, discriminant analysis and density estimation. Journal of the American Statistical Association 97: 611-631.

4. Welch CE (2017) End Tidal Carbon Dioxideas a Prognostic Feature in Pulmonary Arterial Hypertension. ANNALSATS Articles. 
This work is licensed under Creative Commons Attribution 4.0 Licens

DOI: 10.19080/IJOPRS.2017.01.555573
Your next submission with Juniper Publishers will reach you the below assets

- Quality Editorial service

- Swift Peer Review

- Reprints availability

- E-prints Service

- Manuscript Podcast for convenient understanding

- Global attainment for your research

- Manuscript accessibility in different formats ( Pdf, E-pub, Full Text, Audio)

- Unceasing customer service

Track the below URL for one-step submission https://juniperpublishers.com/online-submission.php 